\title{
Plants of Body Symbols in Tri Mandala Tenganan Pegringsingan Village, Karangasem (in Ethnobotany Learning Perspective)
}

\section{Nyoman Wijana*1, Putu Indah Rahmawati², Gusti Agung Nyoman Setiawan ${ }^{3}$, Sanusi Mulyadiharja ${ }^{4}$}

${ }^{1234}$ Jurusan Pendidikan Biologi, Universitas Pendidikan Ganesha

\section{A R T I C L E I N F O}

Article history:

Received 19 January 2019

Received in revised form

10 February 2019

Accepted 12 March 2019

Available online 25 April

2019

Keywords:

Plant Body Symbols, Tri

Mandala, Tenganan

Pegringsingan, Ethnobotany

\begin{abstract}
A B S T R A C T
This research aims to determine (1) the composition of body symbol plant species in each Tri Mandala in the village of Tenganan Pegiringsingan, (2) the coordinate points of reference for body symbol plant species in Tenganan Pegringsingan village, and (3) Plant species perspective body symbol in ethnobotany learning. The method used in this research is quadratic method, observation, and interview. Data were analyzed descriptively. The results of this study indicate (1) from 74 existing plant species, 14 plant species (19\%) included in the body symbol plant category. (2) The distribution of body symbol species on Tri Mandala is categorized as having a wide, medium, or narrow distribution. (3) Coordinating points for the distribution of body symbol plant species ranging from $8^{\circ} 28,506 \mathrm{~S} 115^{\circ} 33,994^{\prime} \mathrm{E}$ to $8^{\circ} 28,646 \mathrm{~S}$ $115^{\circ} 33,995$ '. (4) Plant species body symbols and their distribution to Tri Mandala have a good perspective to be packaged and implemented in ethnobotany learning.
\end{abstract}

\footnotetext{
* Corresponding author.

E-mail addresses: nyomanwijana@gmail.com (Nyoman Wijana)
} 


\section{Introduction}

There have been many studies conducted on terrestrial vegetation. Like research conducted by Arrijani, et al. 2006; Junaedi, et al; 2010; Onrizal, 2010; Onrizal, et al, 2006; Purwaningsih and Yusuf, 2008; Purwaningsih, 2006; Sri, 2007. From these researchers there has not been a study concerning ethnobotany. In this study, it was studied in depth about ethnobotany of body symbol plants in Bali, especially Bali Aga, Tenganan Pegringsingan Village. Balinese people are traditionally divided into groups or soroh or class. Some recitations were the people of Pande, Sangging, Bhujangga Wesnawa, Pasek, Dalem Tarukan, Tegeh Pulasari, Arya, Brahmana Wangsa, Bali Aga and others. The influence of Javanese Hindu culture on Bali led to the existence of the Balinese-Aga community and the Balinese Majapahit community. $B a l i A g a$, is considered as original Bali. The people of Bali Aga, many domiciled in the interior of the mountains such as in the Regency of Buleleng: Sembiran, Cempaga, Sidatapa, and Pedawa Village. In Karangasem Regency are Tenganan Pegringsingan Village, and in Bangli District are Trunyan and Songan Villages (Wijana, 2016).

Tenganan Pegringsingan Village is located in Manggis District, Karangasem Regency, Bali. The village is included in the village of Bali Aga, where the village of Bali Aga is an authentic Balinese village that is not much influenced by the culture of the people belonging to the Bali Majapahit group so that the village has unique customs in managing and preserving its natural environment. Geographically, Tenganan Pegringsingan Village is at an altitude of 50-500 masl, with $620 \mathrm{~mm}$ / year of rainfall, and a temperature range of $28-30^{\circ} \mathrm{C}$. This village has a land area of 917,200 ha with the distribution of rice fields area of 255,840 ha, dry land area of 583,035 ha, and settlements along with social facilities covering an area of 78,325 ha.

In general the livelihoods of the people of Tenganan Pegringsingan village are farmers and some tourism entrepreneurs. The population of Tenganan Pegiringsingan village is 688 people with 232 family heads. There were 333 men and 355 women.
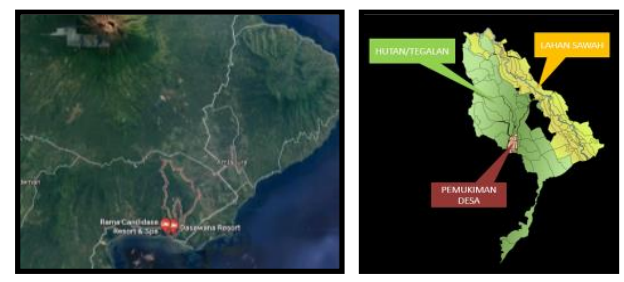

Figure 1.2. Map of Bali Island (Karangasem) (Left) and Map of Tenganan Pegringsingan Village (Right) (Source: Wijana, 2018a)

Tenganan Pegringsingan village in its settlement area consists of three banjars, namely Banjar Kauh, Banjar Tengah, and Banjar Kangin (Pande). According to the village head of Tenganan Pegringsingan, only Banjar Kauh and Banjar Tengah were Bali Aga, while Banjar Kangin was more mingled with Bali Majapahit, so in this study the focus was on the Banjar Adat Kauh and Banjar Adat Tengah areas that became one and often called the Tenganan Pegringsingan Traditional Village consisting of the people of Bali Aga.

The main attraction of Tenganan Pegringsingan village is that this village does not recognize the Ngaben ceremony, but does the Mendem ceremony. Mendem's ceremony means conducting a funeral ceremony instead of being cremated. The conditions for carrying out the burial ceremony must be carried out on the same day as the day of his death. However, if his death in the afternoon, the corpse is kept from being at home for more than 24 hours. One of the Hindu religious ceremonies carried out by the Balinese as a respect for the deceased family is the Ngaben ceremony, or in the Tenganan Pegringsingan community is the Mendem ceremony. Ngaben ceremony is a corpse ceremony in the Balinese Hindu religion where in its implementation it goes through several stages between it Ngulapin, Nyiramin / nyiramang, Ngajum Kajang, Ngaksara, Extortion, Papegatan, Pakiriman / Ngutang, Ngising, Nganyud, and Makelud (Suryadarma, 2007; Kaler , 1993; Nala, 2007; Nala, 2002).

Wijana (2016) states that in order to meet the needs of a variety of plants used in the Ngaben ceremony, Balinese (Hindus) generally plant crops that are needed in certain spaces and land. Traditionally, planting plants that are needed for religious ceremonies (Hinduism), Balinese people consider the meaning and function of these plants, so that the plant pattern is oriented to the Tri Mandala space and the functional philosophy of the plant. Tri Mandala, according to Balinese society, is a division of space based on the belief of "sanctity". The division of space based on Tri Mandala includes the Mandala Utama, Madya Mandala, and Nista Mandala (Suryadarma, 2007; Kaler, 1993; Wesnawa, 2015). 
Ethnobotany as one of the studies of conservation and utilization of ethnic plants or endemic in certain regions by using local wisdom in the region. Local wisdom related to the plant world in Bali is utilized in the world of the Pitra Yadnya ceremony. Balinese people symbolize their body parts into eighteen scripts (hanacaraka) as a form of harmonization of the relationship between the macrocosm and the microcosm. Body parts are characterized by the uniqueness of the hanacaraka script, starting from the head, body, limbs and contents of the body. The visualization is an effort to integrate human beings into their environment as a manifestation of cultivation.

The symbolization of the body script with the uniqueness of plants is expressed narratively in the philosophy of Taru Pinaka Raganta. There are 47 types of body symbols used by Balinese (Hindu) people. The number of plant species can be grouped into 25 families. Plant classification refers to the suitability of plant characteristics and characteristics of body organs and desired expectations. The existence of this type of stir is supported by the existence of a Balinese spatial pattern that relies on the concept of three causes of happiness (Suryadarma, 2007; Wiana, 2007). All types of plants are always used in corpse bathing ceremonies or cremation ceremonies.

Certain plants are planted in certain spaces, according to the philosophy of the level of their needs and or "purity". There are plants that are considered "holy", generally planted in Mandala Utama, and plants that are considered non-planted are planted in Nista Mandala (Nala, 2007; Suryadarma, 2007; Griya, 2007). In the village of Tenganan Pegringsingan, the layout of the spatial plan was also divided into Tri Mandala. In each mandala (space) planted with plants, body symbols are in accordance with the functions and meanings of the body's symbol plants. This study aims to determine (1) the composition of body symbol plant species in each Tri Mandala in Tenganan Pegiringsingan village, Karangasem, Bali; and (2) knowing the coordinates of the point of reference for body symbol plants in Tenganan Pegringsingan village, Karangasem, Bali. (3) Implementation of results of study of body symbol plants in ethnobotany learning in the field in Plant Ecology courses.

\section{Methods}

This research was conducted in Tenganan Pegringsingan Village, Manggis District, Karangasem Regency. The location of the study was only focused on Banjar Kauh and Banjar Tengah because the two banjars had a Balinese Aga community, with centralization of data collection based on the distribution of Tri Mandala spatial plan namely Puseh Sembangan Temple as Utamaning Mandala, Housing as Madyaning Mandala, and Tombs as Nistaning Mandala. The population in this study includes ecosystem and sociosystem parameters, on ecosystem parameters in the form of all plants found in Tenganan Pegringsingan Village. The population in the sociosystem aspect is the community of Tenganan Pegringsingan Village. Samples for ecosystem parameters are body symbol plants found in 33 squares in the Tri Mandala area in Tenganan Pegringsingan Village. The sampling technique uses the stratified random sampling technique with quadratic forms (Wijana, 2014; Mueller-Dombis, 1974; Barbour et al, 1987; Fachrul, 2007; Keith, 1991; Michael, 1995). The size of the square is $10 \times 10 \mathrm{~m} 2$, as many as 33 squares. The sociosystem research sample consisted of three components of society, namely 5 Community Leaders, 5 Religious Leaders, and 5 General Communities so that the total sample of sociosystems was 15 people. This social sample is as an informant in interpreting the body's symbol plants (Best, 1987; Cox, 1976; Niken, 2004). The study area is divided into 3 stations with the placement of squares can be seen in Table 1.

Table 1. Determination of Station and Quadratic Sampling in each Section in Tri Mandala

\begin{tabular}{|c|c|c|c|}
\hline No & Statiun & Squared & Description \\
\hline \multirow{3}{*}{ A } & \multirow{3}{*}{$\begin{array}{l}\text { Station } 1 \\
\text { Mandala Utama Village } \\
\text { (Puseh Sembangan Temple } \\
\text { in the upstream village }\end{array}$} & 1 & $\begin{array}{l}\text { Utamaning Utama (Jero) Main Section } \\
\text { of the Temple located Pelinggih Utama } \\
\text { / Padmasana }\end{array}$ \\
\hline & & 2 & $\begin{array}{l}\text { Utamaning Madya Central part of the } \\
\text { temple, the second area outside Main } \\
\text { Utamaning }\end{array}$ \\
\hline & & 3 & $\begin{array}{l}\text { Utamaning Nista Outside the temple, } \\
\text { the outermost area is a large courtyard. }\end{array}$ \\
\hline B & $\begin{array}{l}\text { Station } 2 \\
\text { Madya Mandala Desa } \\
\text { (Housing, cane / abian / } \\
\text { garden) }\end{array}$ & 4 & $\begin{array}{l}\text { Utamaning Madya Residents' house } \\
\text { includes the area around Jelanan } \\
\text { Awang, Bale Buga, Sanggah Kaja, } \\
\text { Sanggah Kelod. }\end{array}$ \\
\hline
\end{tabular}




\begin{tabular}{|c|c|c|c|c|c|}
\hline \multirow[t]{5}{*}{ No } & \multicolumn{3}{|c|}{ Statiun } & \multirow{2}{*}{$\frac{\text { Squared }}{5}$} & \multirow{2}{*}{\begin{tabular}{l}
\multicolumn{1}{c}{ Description } \\
Madyaning Madya Residents' houses \\
cover the area around Bale Tengah, \\
Bale Meten.
\end{tabular}} \\
\hline & & & & & \\
\hline & & & & 6 & $\begin{array}{l}\text { Nistaning Madya houses cover the area } \\
\text { around the kitchen, and moor. }\end{array}$ \\
\hline & & & & $\ldots$ & Utamaning Madya, Madyaning Madya, \\
\hline & & & & 30 & $\begin{array}{l}\text { and Nistaning Madya follow squares } 4 \text { - } \\
6 \text { to squared } 30 .\end{array}$ \\
\hline \multirow{3}{*}{$\mathbf{C}$} & Station 3 & \multirow{3}{*}{ Mandala } & \multirow{3}{*}{ Desa } & 31 & Utamaning Nista at the cemetery \\
\hline & Nista & & & 32 & Madyaning Nista at the cemetery \\
\hline & (Grave) & & & 33 & Nistaning Nista at the cemetery \\
\hline
\end{tabular}

Data were analyzed descriptively.

\section{Results And Discussion}

The recapitulation of the floristic composition or data of plant species in general which is available in each Tri Mandala is presented in Table 1.

Table 1. Recapitulation of Number of Species, Familia, and Individuals at Each Mandala

\begin{tabular}{lcccc}
\hline \multicolumn{1}{c}{ Category } & Utama Mandala & Madya Mandala & Nista Mandala & Total \\
\hline Number of Species & 38 & 45 & 19 & 74 \\
\hline Number of families & 27 & 29 & 13 & 39 \\
\hline Number of individuals & 169 & 183 & 90 & 442 \\
\hline
\end{tabular}

Based on Table 1, it can be seen that the Puseh Sembangan Temple as Mandala Utama has 38 species of plants, 27 families and the number of individuals as many as 169 individuals. In community housing as Madya Mandala there are 45 species of plants, 29 families and the number of individuals as many as 183 individuals, and in the grave as Nista Mandala there are 19 species of plants, with 13 families and the number of individuals as many as 90 individuals.

Based on the results of the overall plant analysis that lives in the Tri Mandala of the Traditional Village of Tenganan Pegringsingan, further sorting is carried out to find the body symbol plants that are under Tri Mandala's authority. Determination of body symbol plants refers to the list of plants symbolizing the body according to Suryadarma (2007) and (Wijana, 2016), and plant description refers to Heyne (1987). The body symbol plants found in this study are shown in Table 2.

Table 2. Plant Composition of Body Symbols on Tri Mandala

\begin{tabular}{|c|c|c|c|c|c|c|}
\hline No & $\begin{array}{l}\text { Symboli } \\
\text { c Script }\end{array}$ & $\begin{array}{c}\text { Symbolic } \\
\text { Body }\end{array}$ & $\begin{array}{l}\text { Local } \\
\text { Name }\end{array}$ & Scientific Name & Familia & $\begin{array}{c}\text { Amount } \\
\text { Individ } \\
\text { ual }\end{array}$ \\
\hline 1 & $\begin{array}{c}\text { (Ang } \\
\text { Ung } \\
\text { Mang) }\end{array}$ & & $\begin{array}{l}\text { Peji } \\
\text { (daun) }\end{array}$ & $\begin{array}{l}\text { Drymophloeus } \\
\text { oliviformis }\end{array}$ & \multirow{2}{*}{ Arecaceae } & 10 \\
\hline 2 & $(\mathrm{Ta})$ & Breasts & $\begin{array}{l}\text { Kelapa/ } \\
\text { Nyuh } \\
\text { (buah) }\end{array}$ & Cocos nucifera L. & & 19 \\
\hline 3 & $(\boldsymbol{R a})$ & $\begin{array}{l}\text { Hole Ears, } \\
\text { Hair }\end{array}$ & $\begin{array}{l}\text { Kayu } \\
\text { Sugih / } \\
\text { kayu suji } \\
\text { (tangkai } \\
\text { daun) }\end{array}$ & $\begin{array}{l}\text { Dracaena } \\
\text { angustifolia }\end{array}$ & Asparagaceae & 6 \\
\hline 4 & $(T a)$ & Body hair & $\begin{array}{l}\text { Cemara } \\
\text { (daun) }\end{array}$ & $\begin{array}{l}\text { Casuarina } \\
\text { equistifolia }\end{array}$ & Casuarinaceae & 7 \\
\hline 5 & $($ Ang $)$ & Vagina & $\begin{array}{l}\text { Teleng } \\
\text { (bunga) }\end{array}$ & Clitoria ternatea & Fabaceae & 7 \\
\hline
\end{tabular}




\begin{tabular}{|c|c|c|c|c|c|c|}
\hline No & $\begin{array}{l}\text { Symboli } \\
\text { c Script }\end{array}$ & $\begin{array}{c}\text { Symbolic } \\
\text { Body }\end{array}$ & $\begin{array}{l}\text { Local } \\
\text { Name }\end{array}$ & Scientific Name & Familia & $\begin{array}{c}\text { Amount } \\
\text { Individ } \\
\text { ual }\end{array}$ \\
\hline 6 & $\begin{array}{c}\text { (Ang } \\
\text { Ung } \\
\text { Mang) }\end{array}$ & Soul & $\begin{array}{l}\text { Bingin/ } \\
\text { Beringin } \\
\text { (pohon) }\end{array}$ & Ficus benjamina & \multirow{2}{*}{ Moraceae } & 2 \\
\hline 7 & $(B a)$ & visceral & $\begin{array}{l}\text { Nangka } \\
\text { (buah) }\end{array}$ & $\begin{array}{l}\text { Artocarpus } \\
\text { heterophyllus }\end{array}$ & & 6 \\
\hline 8 & $(W a)$ & Nail & $\begin{array}{l}\text { Biu/Pisan } \\
\text { g (bunga) }\end{array}$ & Musa paradisiaca & Musaceae & 18 \\
\hline 9 & $(K a)$ & $\begin{array}{l}\text { Hole } \\
\text { nose }\end{array}$ & $\begin{array}{l}\text { Pusuh } \\
\text { Menuh / } \\
\text { Melati } \\
\text { (bunga) }\end{array}$ & Jasminum sambac & Oleaceae & 3 \\
\hline 10 & $(\mathrm{Nga})$ & Penis & $\begin{array}{l}\text { Tabia Bun } \\
\text { / Cabe } \\
\text { Jawa } \\
\text { (buah) }\end{array}$ & Piper retrofractum & Piperaceae & 5 \\
\hline 11 & $(D a)$ & Mouth & $\begin{array}{l}\text { Kecubung } \\
\text { pendek } \\
\text { (bunga) }\end{array}$ & Datura metel & \multirow{3}{*}{ Solanaceae } & 4 \\
\hline 12 & $(N g a)$ & Fine hair & $\begin{array}{l}\text { Tuung } \\
\text { dawe/ } \\
\text { Terong } \\
\text { (buah) }\end{array}$ & $\begin{array}{l}\text { Solanum } \\
\text { melongena }\end{array}$ & & 7 \\
\hline 13 & $(J a)$ & Heel & $\begin{array}{l}\text { Tuung } \\
\text { bulet/ } \\
\text { Terong } \\
\text { kokak } \\
\text { (buah) }\end{array}$ & Solanum torvum & & 9 \\
\hline 14 & $(S a)$ & Fingers & $\begin{array}{l}\text { Kunyit } \\
\text { (umbi) }\end{array}$ & Curcuma longa L. & Zingiberaceae & 6 \\
\hline \multicolumn{5}{|c|}{ Total } & 10 Familia & $\begin{array}{c}109 \\
\text { Individ } \\
\text { uals }\end{array}$ \\
\hline
\end{tabular}

Referring to Table 2, it can be seen that in Tri Mandala the Tenganan Pegringsingan Village has 14 species of plants which are included in the body symbol plant category, 14 of these species fall into 10 families, and 109 individuals. Thus, in Tri Mandala there are 19\% of the body's symbol plant species from a total of 74 species of plants that exist, and there are $25.6 \%$ of body plants from 39 families, and there are $24.66 \%$ of the body symbols of the total plant 442 individuals in the Tri Mandala of Tenganan Pegringsingan Village.

From the plant data of the existing body symbols, the plants of Coconut/kelapa (Cocos nucifera L.) as a symbol of plant species show the highest number of individuals, namely 19 individuals, in the second there are Bananas/pisang (Musa paradisiaca) as symbols of the fingers and toes, which have 18 individuals, then there are Peji (Drymophloeus oliviformis) as symbols of the body with 10 individuals. The symbol of the body with the least number of individuals is the Banyan (Ficus benjamina) as a psychic symbol, which only has 2 individuals, then there is Melati (Jasminum sambac) as a symbol of the nostril, only has 3 individuals, and Kecubung (Datura metel) as a symbol mouth, third place with the least number of individuals, namely 4 individuals.

The distribution of body symbol plant species based on their place of life in each mandala/space is presented in Table 3. The distribution of this species is categorized as having a broad, medium, or narrow distribution. The broad distribution means that if the body's symbolic species of plants are spread over three mandalas, while those with moderate distribution if the body's species of plant symbols are found in two mandalas. For a narrow distribution if the body's symbol plant species is only found in one mandala. 
Table 3. Distribution of Plant Species Body Symbols of Tenganan Pegringsingan Village

\begin{tabular}{|c|c|c|c|c|c|}
\hline \multirow[b]{2}{*}{ No } & \multirow{2}{*}{$\begin{array}{c}\text { Local Name and } \\
\text { Scientific Name of Plant }\end{array}$} & \multicolumn{3}{|c|}{ Location } & \multirow{2}{*}{$\begin{array}{l}\text { Distribution } \\
\text { Category }\end{array}$} \\
\hline & & $\begin{array}{c}\text { Utama } \\
\text { Mandala }\end{array}$ & $\begin{array}{c}\text { Madya } \\
\text { Mandala }\end{array}$ & $\begin{array}{c}\text { Nista } \\
\text { Mandala }\end{array}$ & \\
\hline 1 & $\begin{array}{l}\text { Kelapa (Cocos nucifera } \\
\text { L.) }\end{array}$ & + & + & & medium, \\
\hline 2 & $\begin{array}{l}\text { Teleng } \\
\text { ternatea) }\end{array}$ & + & + & & medium \\
\hline 3 & $\begin{array}{l}\text { Terong Panjang } \\
\text { (Solanum melongena) }\end{array}$ & & + & + & medium \\
\hline 4 & $\begin{array}{l}\text { Cemara } \\
\text { equistifolia) }\end{array}$ & + & & & narrow \\
\hline 5 & $\begin{array}{l}\text { Kecubung (Datura } \\
\text { metel) }\end{array}$ & + & & & narrow \\
\hline 6 & $\begin{array}{l}\text { Peji (Drymophloeus } \\
\text { oliviformis) }\end{array}$ & + & & & narrow \\
\hline 7 & $\begin{array}{l}\text { Kayu Sugih (Dracaena } \\
\text { angustifolia) }\end{array}$ & & + & & narrow \\
\hline 8 & $\begin{array}{l}\text { Kunyit (Curcuma longa } \\
\text { L.) }\end{array}$ & & + & & narrow \\
\hline 9 & $\begin{array}{l}\text { Melati } \\
\text { sambac) }\end{array}$ & & + & & narrow \\
\hline 10 & $\begin{array}{l}\text { Nangka (Artocarpus } \\
\text { heterophyllus) }\end{array}$ & & & + & narrow \\
\hline 11 & $\begin{array}{l}\text { Beringin } \\
\text { benjamina })\end{array}$ & & & + & narrow \\
\hline 12 & $\begin{array}{l}\text { Pisang } \\
\text { paradisiaca) }\end{array}$ & & & + & narrow \\
\hline 13 & $\begin{array}{l}\text { Tabia Bun } \\
\text { retrofractum) }\end{array}$ & & & + & narrow \\
\hline 14 & $\begin{array}{l}\text { Terong Kokak (Solanum } \\
\text { torvum) }\end{array}$ & & & + & narrow \\
\hline
\end{tabular}

Description + meaning exists

Referring to Table 3 there are three body symbol plants which are included in the medium distribution, as many as 13 other body symbol plants have a narrow distribution, which means they can only be found in one mandala.

Point coordinates of the distribution of body symbol plant species for Tri Mandala in Tenganan Pegringsingan village are presented in Table 4.

Table 4. Coordinate Points of Plant Species Body Symbols in the Tri Mandala of Tenganan Pegringsingan Village

\begin{tabular}{clcc}
\hline \multirow{2}{*}{ No } & \multicolumn{2}{c}{$\begin{array}{c}\text { Local Name and Scientifc Name of } \\
\text { Plant }\end{array}$} & \multicolumn{2}{c}{ Distribution Coordinate Points } \\
\cline { 2 - 3 } & \multicolumn{2}{c}{ 'S } \\
\hline 1 & Beringin (Ficus benjamina) & $8^{\circ} 28.506^{\prime}$ & $115^{\circ} 33.994^{\prime}$ \\
\hline 2 & Cemara (Casuarina equistifolia) & $8^{\circ} 28.330$ & $115^{\circ} 34.064^{\prime}$ \\
\hline 3 & Kayu Sugih (Dracaena angustifolia) & $8^{\circ} 28.446^{\prime}$ & $115^{\circ} 34.976^{\prime}$ \\
\hline 4 & Kecubung (Datura mete) & $8^{\circ} 28.335^{\prime}$ & $115^{\circ} 34.037^{\prime}$ \\
\hline 5 & Kelapa (Cocos nucifera L.) & $8^{\circ} 28.436^{\prime}$ & $115^{\circ} 34.972^{\prime}$ \\
\hline 6 & Kunyit (Curcuma longa L.) & $8^{\circ} 28.452^{\prime}$ & $115^{\circ} 33.995^{\prime}$ \\
\hline 7 & Melati (Vasminum sambac) & $8^{\circ} 28.482$ & $115^{\circ} 34.972^{\prime}$ \\
\hline 8 & Nangka (Artocarpus heterophyllus) & $8^{\circ} 28.504$ & $115^{\circ} 33.967^{\prime}$ \\
\hline 9 & Peji (Drymophloeus oliviformis) & $8^{\circ} 28.436^{\prime}$ & $115^{\circ} 33.974$ \\
\hline 10 & Pisang (Musa paradisiaca) & $8^{\circ} 28.528^{\prime}$ & $115^{\circ} 33.986^{\prime}$ \\
\hline 11 & Tabia Bun (Piper retrofractum) & $8^{\circ} 28.530$ & $115^{\circ} 34.965^{\prime}$ \\
\hline 12 & Teleng(Clitoria ternatea) & $8^{\circ} 28.504$ & $115^{\circ} 33.986^{\prime}$ \\
\hline
\end{tabular}




\begin{tabular}{clll}
\hline 13 & Terong Kokak (Solanum torvum) & $8^{\circ} 28.646^{\prime}$ & $115^{\circ} 34.036^{\prime}$ \\
\hline 14 & Terong Panjang (Solanum melongena) & $8^{\circ} 28.646^{\prime}$ & $115^{\circ} 33.995^{\prime}$ \\
\hline
\end{tabular}

The plant distribution coordinate points above are analogous to the research conducted by Wijana (2017; 2018a,b,c; Wijana dan Setiawan 2018a,b). In more detailed research, a mapping of plant propagation in general is specifically made for rare plants in the tourist forest of the province of Bali.

In lectures on Plant Ecology, especially vegetation analysis (Wijana, 2014), the overall lecture model takes place in the field. Analysis of vegetation is directed at terrestrial vegetation. Thus the object of study used as a field study is forest vegetation, moor vegetation, housing vegetation, and weed vegetation in rice fields. In the analysis of vegetation that is generally carried out is the spectrum of life forms, distribution patterns of plant species, association of plant species, stand structure, method of vegetation analysis without plotness method, analysis of plant diversity, ordination and more implementable studies of ethnobotany. In addition to this concerning ethnobotany study concerning Plant Ecology, it is also integrated with the local culture, local genius and local wisdom in the village. By referring to the results of research that has been conducted, and / or broadly elaborated, the implementation of this research is modeled on analysis. diversity of body symbol plants at the location of this research site or in another place / location. By referring to the research method and data from the results of the research that has been conducted, the implementation of the learning can be presented as follows.

Title : Analysis of plant species diversity Body symbols (Ethnobotany)

Objective : : Students are able to analyze the diversity of plant species symbol of the body

Tools and materials : A set of ecological tools and soil test kits

How it works : Look again at the work method or method used in this study (Wijana, 2014; Mueller-Dombis, 1974; Barbour et al, 1987; Fachrul, 2007; Keith, 1991; Michael, 1995).

Field observations: enter data from field observations about vegetation parameters as in the work table below.

Table 5. Field observations

\begin{tabular}{|c|c|c|c|}
\hline $\begin{array}{c}\text { NAME OF PLANT } \\
\text { SPECIES OF BODY } \\
\text { SYMBOLS }\end{array}$ & $\begin{array}{l}\text { NUMBER OF } \\
\text { INDIVIDUALS }\end{array}$ & ABUNDANCE & $\begin{array}{l}\text { SYMBOLIZATION IN } \\
\text { BODY ORGANTS }\end{array}$ \\
\hline 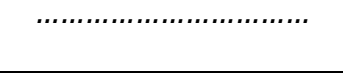 & ......... & . & ...... \\
\hline (n) & (n) & 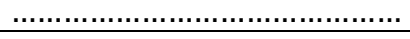 & (n) \\
\hline $\begin{array}{c} \\
.\end{array}$ & (n) & (n.......... & (......... \\
\hline $\begin{array}{l}\text { NUMBER OF } \\
\text { INDIVIDUALS }\end{array}$ & 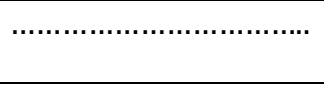 & f.......................... & (n) \\
\hline $\boldsymbol{\Sigma}$ ABUNDANCE $(\boldsymbol{\delta})$ & & & (n.m. \\
\hline SIMPSON INDEKS (D) & & $\cdots \cdots$ & $\cdots \cdots$ \\
\hline
\end{tabular}

To find the Abundance Index using the formula:

$$
\delta=\frac{\sum \text { ni (ni-1) }}{\text { N }(\mathrm{N}-1)}
$$

$\delta=$ dominance $/$ abundance index

$\mathrm{ni}=$ number of species individuals $\mathrm{i}$

$\mathrm{N}=$ number of individuals

To find diversity based on Indedks Simpson the formula is used: (Ludwig, 1984; Wijana, 2014).

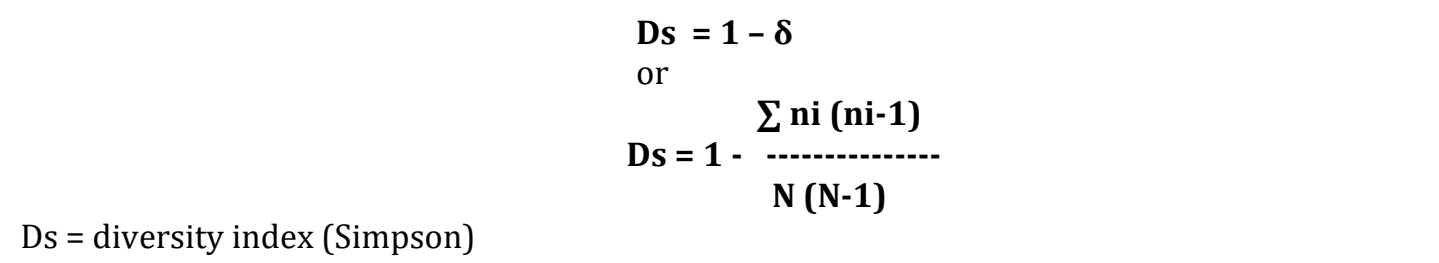


Data interpretation : students interpret the results of data analysis as done above.

Discussion : students discuss the results of data analysis and data interpretation based on the study of theory and research results.

Conclusion

: students make conclusions from the results of data analysis, data interpretation and the results of the discussion.

The composition of the body symbol plant species shows that there are $25 \%$ of individual plants symbolized by the body of all plants in Tri Mandala. As already stated in the introduction, that the body symbol plants in Tenganan Pegringsingan Village are not used as body symbols in the Nyiramin stage at the Ngaben ceremony. This fact is based on the testimony of the community, which explains that in the village of Tenganan Pegringsingan as a village with the people of Bali Aga that is different from other Bali Aga and Bali's Majapahit generally in Bali. In spatial distribution, it still refers to the Tri Mandala pattern, but the use of body symbol plants as a symbol of body organs (Tri Angga) is not used as a Balinese (Hindu) community in general. The implementation of the Nyiramin ceremony as carried out by Balinese (Hindu) people in general, uses a number of plants as a symbol of Tri Angga. While the Tenganan Pegringsingan community did not carry out the Nyiramin ceremony, but did the Mendem (burying the body) ceremony which the procession ceremony did not use banten like the Balinese (Hindus) generally. The provisions for Mendem are bodies must be buried / Mendem immediately on the same day as the day of death of the person, except the event of death in the afternoon or evening. Other provisions that need to be considered by the local community are not allowed to bury the bodies / Mendem two days in a row. This is believed by the local community, will be able to cause the incidence of death continuously.

The number of individual symbol plant species on Tri Mandala in the village reaches $25 \%$. This is an indication that the body's symbol plants have other functions and uses and are conservative and social. This social nature can be provided free of charge to other people from outside the village, who need it for religious (Hindu) ceremonies. Thus tolerance, mutual respect, mutual reconciliation, mutual jealousy, etc. are highly reflected in the lives of traditional people.

As already stated in advance that the tourist attraction that is already known in the village of Tenganan Pegringsingan is a cultural destination. The culture that is the main attraction for the village is the Tari Perang Pandan (Pandan war dance), traditional weaving products in the form of Tenganan Pegringsingan woven fabric, traditional buildings, road arrangement that still shows megalithic times. In terms of natural resources, such as view of nature, geographical indications, or in the form of other natural resources (Achmad, 2012; Anggraini, 2011), it has not provided a special attraction.

Related to this body symbol plant distributed to Tri Mandala Tenganan Pegringsingan village can be used to contribute to the prospect of the existing destinations in the village of Tenganan Pegringsingan can be presented as follows. (1) Tracking route along the Bukit Kangin. On Bukit Kangin, plants are spread with species diversity index which is included in the medium-high category. This hill is quite green with existing vegetation. Along the plant route tracking route is given a local name and scientific name label and accompanied by a description of the plant. (2) Introduction of Tri Mandala in the village of Tenganan Pegringsingan. With the unique spatial layout in the village accompanied by a natural arrangement of plants, it gives a distinct impression for visitors. The existence of a special show room room to provide about the meaning of the existing layout and buildings will provide a special attraction for tourists. (3) A combination of culture and ritual. The culture of Mendem ceremonies or funeral bodies or Perang Pandan (pandan war) rituals that are truly unique and endemic, by utilizing various types of existing plants, can be reconstructed and given descriptions of the plant's body symbols that are used, so that the meaning and morphology of the plant has strong and relevant links. (4) Various products produced by local communities that already exist, such as loloh (Herb), woven fabric, palm wine, palm leaves, etc. need to be packaged further so that it becomes an attraction for visitors as souvenirs that are typical of Tenganan Pegringsingan Village. (5) Looking for new products that are typical of Tenganan Pegringsingan Village, such as products from athe plants, and copying plants that can be utilized in home industries. The symbol of the body plantsw can be packaged in the form of a plant nursery, the making of a garden for a symbol of the body, or in the form of a plant symbol of the body, a socially beneficial plant where local plants can.

In the implementation of the results of this study as mentioned above, it can be packaged in field studies especially in ethnobotany studies. In ethnobotany studies, it not only concerns local plants (endemic) but also concerns local integration, local genius and local wisdom (Wijana, 2016; 2017; $2018 \mathrm{a}, \mathrm{b}, \mathrm{c})$ 


\section{Conclusion}

From the results of this study it can be concluded (1) in Tri Mandala Tenganan Pegringsingan Village has 74 species of plants that belong to 39 families. (2) Of the 74 plant species, 14 plant species (19\%) are included in the body symbol plant category. (3) The distribution of body symbol species on Tri Mandala is categorized as having a wide, medium, or narrow distribution. (4) The point of coordinates for the distribution of body symbol plant species ranging from $8^{\circ} 28,506 \mathrm{~S} 115^{\circ} 33,994$ 'E to $8^{\circ} 28,646$ 'S 115 33,995 '. (5) Plant species symbol of the body and its distribution to Tri Mandala have good tourism prospects when packaged and promoted well. (5) The body symbol plants for the people of Tenganan Pegringsingan village, are not used properly as in the general Balinese (Hindu) community, but can be used as a conservative and social function. In implementing ethnobotany studies, research results can be packaged to be used as field studies. Suggestions that can be conveyed are that body symbol plants need to be conserved, packaged in the frame of tourism, education and destination promotion.

\section{Reference}

Achmad, Amran. 2012. Identifikasi Tutupan Vegetasi dan Potensi Fisik Lahan untuk Pengembangan Ekowisata di Laboratorium Lapangan Konservasi Sumberdaya Hutan dan Ekowisata Hutan Pendidikan UNHAS. Jurnal Penelitian Kehutanan Wallacea, Volume 1, Nomor 2 (hlm. 87)

Anggraini, Melyana. 2011. Penilaian Kualitas Lingkungan pada Kegiatan Wisata Alam di Kawasan Ekowisata Tangkahan. Skripsi. Program Studi Kehutanan, Fakultas Pertanian, Universitas Sumatera Utara.

Arrijani; Dede Setiadi; Edi Guhardja; Ibnul Qayim. 2006. Analisis Vegetasi Hulu DAS Cianjur Taman Nasional Gunung Gede-Pangrango. Jurnal Biodiversitas. Vol.7 No. 2, April 2006. h: 147-153.

Barbour, M. G; J. H. Burk and W. D. Pitts. 1987. Terrestrial Plant Ecology. Inc. California : The Benjamin/ cummings Publishing Company.

Best, John W. 1982. Metodologi Penelitian Pendidikan. Surabaya : Usaha Nasional.

Cox, G.W. 1976. Laboratory Manual of General Ecology. WM. C. Brown Company Publisher, USA.

Fachrul, Melati Ferianita. 2007. Metode Sampling Bioekologi. Jakarta: PT Bumi Aksara.

Geriya, I Wayan. 2007. Konsep dan Strategi Revitalisasi Kearifan Lokal dalam Penataan Lingkungan Hidup Daerah Bali. Dalam Buku Kearifan Lokal Dalam Pengelolaan Lingkungan Hidup. Denpasar : UPT Penerbit Universitas Udayana.

Heyne, K. 1987. Tumbuhan Berguna Indonesia Jilid I, II, III, dan IV. Jakarta: Badan Penelitian dan Pengembangan Departemen Kehutanan.

Junaedi, Decky Indrawan dan Zaenal Mutaqien. 2010. "Diversity of Tree Communities in Mount Patuha Region, West Java". Biodiversitas, Volume 11, Number 2. April 2010. ISSN: 1412-033X (Pages: 7581).

Kaler, I. G. K. 1993. Ngaben : Mengapa Mayat Dibakar?. Denpasar : Yayasan Dharma Narada.

Keith, Lawrence H. 1991. Environemental Sampling and analysis : a Practical Guide. Florida : Lewis Publishers.

Michael P. 1995. Metode Ekologi untuk Penyelidikan Ladang dan Laboratorium. Jakarta: Universitas Indonesia Press.

Mueller-Dombois, D., H. Ellenberg. 1974. Aims and Methods of Vegetation Ecology. Sanfransisco : W. H. Freeman and Company. 
Nala, N. 2007. Usada Bali: Tinjauan Filosofis dan Peranannya Dalam Ekowisata. Dalam Prosiding Seminar Konservasi Tumbuhan Usada Bali dan Peranannya Dalam Mendukung Ekowisata Tahun 2007. Tabanan, Bali: UPT Balai Konservasi Tumbuhan Kebun Raya Eka Karya Bali-LIPI.

Nala. N. 2002. Balinese Traditional Cultural in Changing World. Dalam I.G.N Susila, Editor. Proceeding National-International Seminar Traditional Culture in Changing World. March 22. Denpasar : Bali HESG.

Niken, Wirasanti,. 2004. Dampak Pada Komponen Sosial. Yogyakarta: PSLH- UGM.

Onrizal. 2010. Perubahan Tutupan Hutan Mangrove di Pantai Timur Sumatera Utara Periode 1977 - 2006. Jurnal Biologi Indonesia. Vol. 6. No. 2. Juni 2010. Hal. 163 - 172. ISSN 0854-4425.

Onrizal; Cecep Kusmono; Bambang Hero Saharjo; Iin P. Handayani; Tsuyoshi Koto. 2006. "Analisis Vegetasi Hutan Hujan Tropika Dataran Rendah Sekunder di Taman Nasional Danau Sentarum, Kalimantan Barat". Jurnal Biologi, Volume. 4. Nomor 6. Desember 2006. ISSN 0853-7240 (hal. 359371).

Purwaningsih dan Razali Yusuf. 2008. "Analisis Vegetasi Hutan Pegunungan di Taman Nasional Gunung Ciremai, Majalengka, Jawa Barat”. Jurnal Biologi Indonesia 4 (5) : 385-399 Tahun 2008.

Purwaningsih. 2006. "Analisis Vegetasi Hutan pada Beberapa Ketinggian Tempat di Bukit Wawouwai, Pulau Wawonii Sulawesi Tenggara". Jurnal Biodiversitas, Volume 7, Nomor 1. Januari 2006. ISSN 1412-083 (hal. 49-53).

Sri Hartini. 2007. Keragaman Flora dari Monumen Alam Kersik Luway Kalimantan Timur. Jurnal Biodiversitas Vol. 8, Nomor 1. Januari 2007. hal. 67-72. ISSN 1412-083.

Suryadarma, I Gusti Putu. 2007. Konservasi Tumbuhan Obat Usada Bali Dalam Perspektif Ekowisata. Dalam Prosiding Seminar Konservasi Tumbuhan Usada Bali dan Peranannya Dalam Mendukung Ekowisata Tahun 2007. Tabanan, Bali: UPT Balai Konservasi Tumbuhan Kebun Raya Eka Karya Bali-LIPI.

Wesnawa, Astra Gede. 2015. Kelestarian Budaya Dan Adat Bali Dalam Permukiman Perdesaan. Buku Ajar. Singaraja: Penerbit Undiksha.

Wiana, I Ketut. 2007. Konsep Hindu Tentang Pelestarian Lingkungan. Dalam Buku Kearifan Lokal Dalam Pengelolaan Lingkungan Hidup. Denpasar: UPT Penerbit Universitas Udayana.

Wijana, N. 2002. Analisis Vegetasi dan Kontribusi Masyarakat Setempat dalam Konservasi Hutan di Desa Tenganan Pegringsingan Kecamatan Manggis Kabupaten Karangasem. Laporan Penelitian. Tidak diterbitkan.

Wijana, Nyoman dan I Nengah Sumardika. 2009. Pelestarian Jenis-Jenis Tumbuhan Berguna Melalui Kearifan Lokal di Desa Adat Tenganan Pegringsingan, Kabupaten Karangasem, Bali. Dimuat dalam prosiding Konservasi Flora Indonesia dalam Mengatasi Dampak Pemanasan Global. Kebun Raya “Eka Karya - LIPI. Hal. 724 - 731. ISBN 978-979-799-447-1.

Wijana, Nyoman. 2008. Keanekaragaman Spesies Tumbuhan, Manfaat dan Upaya Pelestarian oleh Masyarakat Desa Adat Tenganan Pegringsingan, Karangasem. Jurnal Wahana Matematika dan Sains. Vol.5 No. 10, Oktober 2008. h:17-34.

Wijana, Nyoman. 2014. Metode Analisis Vegetasi. Jogjakarta: Graha Ilmu.

Wijana, Nyoman. 2016. Pengelolaan Lingkungan Hidup (Aspek Kearifan Lokal, Ergonomi, Ergologi, dan Regulasi). Singara.

Wijana, Nyoman. 2017. Pemetaan Pencaran dan Pola sebaran Spesies Tumbuhan Langka di Hutan Wisata Provinsi Bali. Hasil Penelitian. 
Wijana, Nyoman. 2018a. The Measurement Of Rare Plants Learning Media Using Backward Chaining Integrated With Context-Input-Process-Product Evaluation Model Based On Mobile Technology. International Journal of Advance Computer Science And Application. The Science And Information (SAI) Organization. Vol. 9 No. 8 2018. pp:265-277.

Wijana, Nyoman. 2018b. The Formation of Mini Illustrated Dictionary of Rare Plant in The Village Forest of Penglipuran, Bangli, Bali. Journal of Physics: Conference Series 1040 (2018) 012008

Wijana, Nyoman. 2018c. The Mapping of Rere Plant Species Distribution in Monkey Forest, Ubud, Gianyar, Bali. Jurnal Media Komunikasi Geografi (MKG). MKG Vol.19.No. 1. Juni 2018 (23-30) @ FHIS Undiksha dan IGI ISSN 0216-8138.

Wijana, Nyoman dan I Gusti Agung Nyoman Setiawan. 2018a. Plant Spesies Mapping And Density In The Village Forest Of Penglipuran, Bangli, Bali, Indonesia And Its Use In Learning Media. International Journal Of Natural Science And Engineering. Universitas Pendidikan Ganesha.

Wijana, Nyoman dan I Gusti Agung Nyoman Setiawan. 2018b. Rare Plant Preservation Through Village Forest Policy In Bali. Advance In Sosial Science, Education And Humanities Research Atlantis Press.. 